\title{
Experience of migrant self-employment as ,economisation of ethnicity”. Indian and Chinese entrepreneurs in Poland ${ }^{2}$
}

The article presents the concept of "economisation of ethnicity" understood as a strategy of taking advantage of cultural resources of ethnic groups in conducting business activities. On the example of the Chinese and Indian communities it explores different ways and patterns of using ethnic cultural and ethnic social capital for the development of own enterprises. Such strategies involve for example: attracting ethnic customers, employing ethnic workers, offering ethnic goods. However, "economisation of ethnicity" means using ethnicity in a non-alienating manner. It includes also efforts of integration with the host society, for example good knowledge of Polish language and culture. The article is based on the official statistical data and results of the qualitative research conducted in years 2014-2017 within the grant project financed by the National Science Centre.

Keywords: ethnic entrepreneurship, migrant self-employment, economisation of ethnicity, Chinese migration, Indian migration

\section{Introduction. The concept of economisation of ethnicity in business activities}

Poland is increasingly multicultural, both in terms of demographic structure of society and political framework (migration and integration policy). The migration streams are dominated by foreigners from post-Soviet countries, especially

\footnotetext{
${ }^{1}$ Corresponding author: Katarzyna Andrejuk, kandrejuk@ifispan.waw.pl

2 The research project was financed by the National Science Centre, decision number DEC-2013/ 09/D/HS6/03430
} 
Ukraine, which is currently the sending state of the largest immigrant group. However, the populations of third country nationals from outside the post-Soviet area are growing too. The article will examine the two of these groups, distinguished because of being particularly entrepreneurial. We study the self-employed immigrants from China and India in Poland from the perspective of economisation of ethnicity.

Pursuant to the lexical meaning, the notion of "economisation" denotes making economical use of something. "To economise" means to practice economy, to avoid waste or extravagance. As economisation of ethnicity, we understand making specific use of cultural resources connected with the ethnic status: taking advantage of ethnicity in the business sphere while at the same time reducing the negative impact of ethnicity in other spheres of life (for example by acquisition of a stable legal status, or by learning a language). In the process of economisation of ethnicity, cultural and social ethnic capital is reorganised by exposure to the market sources. The adverse impact of ethnicity and migrant status has been recognized in the literature as: barriers experienced during the job search and foreigners' more difficult access to prestigious jobs; migrants' lower wages in comparison to natives; higher vulnerability and risk of unemployment during economic slowdown (see i.a.: Kogan 2004; Dustman, Glitz, Vogel 2010). These findings indicate that in the process of integration in the labour market, migrants are required to actively manage the risks connected with the market perception of their origins. Parallel with the process of marketization of ethnic resources, the negative effect of ethnicity is diminished. Individuals strategize and make rational choices of integrating with the host society in order to improve the conduct of their business activities. The process of economisation means that ethnic resources are managed in diverse ways to produce certain gratifications. By deploying the notion of economisation we also emphasise the act of conferring economic significance to specific cultural resources and behaviours, which tend to be framed mainly in the symbolic and emotional context. This approach indicates the key role of instrumental rationality in human action: individuals are presented as active decision-makers who make choices between alternative means to optimise their utility with the minimum effort (Çalışkan, Callon 2009: 373).

The concept of economisation of ethnicity consists of two fundamental dimensions. The first is the aspect of integration with the host society. Pursuant to the existing research on migrant integration in Western Europe, integration efforts such as naturalisation improve performance in the labour market (eg. Bevelander, Veenman 2006). Also entrepreneurs are more successful if they are integrated with the host society in the legal and cultural dimension. The legal dimension of integration is associated with a stable legal status. In Poland, entrepreneurs have more opportunities to register and develop business activities if they possess a steady secure status such as permanent residency card, or status of a long term EU resident. 
This is connected with various factors of cultural integration, which are required by law if one applies for such legal status. They include good knowledge of Polish and residing in Poland for a certain amount of time (e.g. 5 years in the case of long-term EU residents). As a consequence, immigrants who want to develop own business in Poland have more chances to do that if they demonstrate a high level of legal, cultural and social integration with the host society. This aspect of immigrant business activities often remains unnoticed, because research concentrates solely on the mechanisms and patterns of using cultural background by migrants. Ignoring this aspect of ethnic entrepreneurship constitutes a serous research gap in migration studies which we address in our concept.

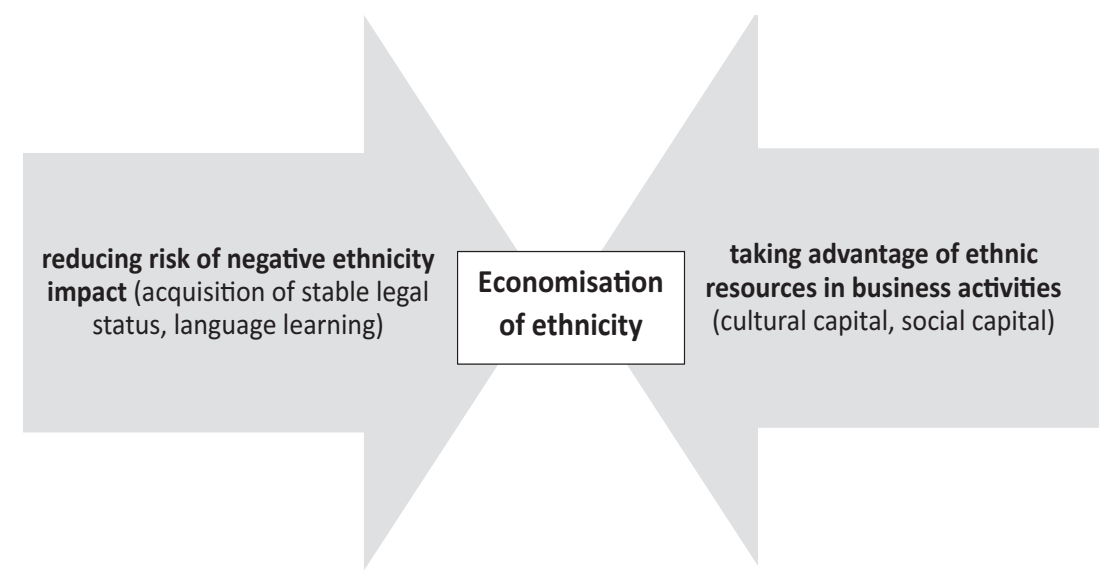

Source: own elaboration

The second dimension of the economisation of ethnicity is the usage of ethnic resources in business activities. It is often referred to as "commodification of ethnicity", understood as instrumental usage of cultural assets connected with ethnic identity in economic activities (Comaroff, Comaroff 2009). According to Comaroff and Comaroff, the ethnicity understood as a repertoire of cultural signs is transformed in the process of adaptation to the market: some elements are emphasised in order to make ethnicity attractive for potential customers. Using ethnic resources in business may have very different forms. Many immigrant firms operate in ethnic enclaves, which make it easier to hire co-ethnic workers or attract customers with ethnic origins (Zhou 2004; Wilson, Portes 1980). Moreover, the globalisation and interest in multiculturalism causes that the native populations are increasingly attracted to ethnic products and services. In each of these mechanisms, the cultural background is used as a strategy of maximising profits. It provides competitive advantage in business operations. 


\section{Research method}

The research methods consist of the qualitative element (analysis of interviews) and quantitative element (analysis of the official statistical data). The official data about foreigners from China and India countries and their entrepreneurial activities encompass the data acquired by international institutions (OECD) as well as Polish institutions (Central Statistical Office, Ministry of Family, Work and Social Policy, to some extent ZUS). In the qualitative part, nine interviews with the Indian entrepreneurs and six interviews with the Chinese entrepreneurs developing their firms in Poland were conducted. The search for respondents was performed with the use of both the official sources (contacting people from the publicly available CEIDG database) and the unofficial channels (networking, snowball sampling).

The Indian interviewees were 2 females and 7 males. The Chinese interviewees were 3 females and 5 males (one of the interviews was collective, encompassed Chinese husband, Chinese wife and their co-ethnic business partner). The respondents worked in Warsaw and surroundings (Wólka Kosowska), Wrocław, Szczecin. They developed their firms as companies as well as individual business activities (działalność gospodarcza osoby fizycznej). They were active in various branches: trade, gastronomy, travel agency, alternative medicine, IT. The interviews took place between 2014 and 2016. They were conducted face-to-face in the cases of respondents residing in the mazowieckie voivodship. Skype interviews were arranged for respondents living in other Polish cities. The interviews were conducted in Polish, Chinese - Mandarin and English.

\section{Chinese and Indian communities in Poland}

The Chinese and the Indian migrants are very interesting groups to compare because of the cultural differences between the two communities but on the other hand the similarity of their legal status and mobility patterns. The Chinese and Indians migrating to the European Union most frequently choose Western European states. In case of both groups, the states with largest inflows are Germany and the United Kingdom. It can be explained both by economic factors as well as by the historical ties between the UK and India, the former colony of the British Empire. However, Central European states also receive migration streams from China and India. In the period 2010-2015, Poland has been the most important destination country for these groups in the Central European region. It receives the largest migration flows. In 2015, the number of Indian immigrants coming annually to Poland exceeded the inflows to Slovak Republic, Hungary, and Czech Republic (combined). In the same year, the inflow of Chinese was the largest in the region, too. 
Table 1 .

Inflow of Chinese migrants to selected European states (2010-2015)

\begin{tabular}{|l|r|r|r|r|r|r|}
\cline { 2 - 7 } \multicolumn{1}{c|}{} & $\mathbf{2 0 1 0}$ & $\mathbf{2 0 1 1}$ & $\mathbf{2 0 1 2}$ & $\mathbf{2 0 1 3}$ & $\mathbf{2 0 1 4}$ & $\mathbf{2 0 1 5}$ \\
\hline Czech Republic & 459 & 325 & 400 & 376 & 496 & 469 \\
\hline Estonia & 26 & 32 & 22 & 50 & 12 & 55 \\
\hline Germany & 16248 & 18276 & 19740 & 22350 & 23163 & 25511 \\
\hline Hungary & 1141 & 883 & 1137 & 2165 & 4718 & 3524 \\
\hline Italy & 22866 & 20055 & 20463 & 17592 & 15828 & 14866 \\
\hline Poland & 2267 & 2785 & 2911 & 2997 & 1630 & 3759 \\
\hline Slovak Republic & 616 & 387 & 71 & 36 & 24 & 28 \\
\hline United Kingdom & 28000 & 45000 & 41000 & 46000 & 39000 & 43000 \\
\hline
\end{tabular}

Source: own elaboration based on the OECD data

Table 2 .

Inflow of Indian migrants to selected European states (2010-2015)

\begin{tabular}{|l|r|r|r|r|r|r|}
\cline { 2 - 7 } \multicolumn{1}{c|}{} & $\mathbf{2 0 1 0}$ & $\mathbf{2 0 1 1}$ & $\mathbf{2 0 1 2}$ & $\mathbf{2 0 1 3}$ & $\mathbf{2 0 1 4}$ & $\mathbf{2 0 1 5}$ \\
\hline Czech Republic & 230 & 208 & 288 & 313 & 428 & 550 \\
\hline Estonia & 11 & 20 & 28 & 47 & 25 & 80 \\
\hline Germany & 13187 & 15352 & 18063 & 19455 & 22374 & 26113 \\
\hline Hungary & 318 & 356 & 260 & 211 & 355 & 512 \\
\hline Italy & 15246 & 13327 & 11158 & 10814 & 11052 & 11236 \\
\hline Poland & 1201 & 1077 & 1151 & 1214 & 785 & 1881 \\
\hline Slovak Republic & 103 & 39 & 2 & 8 & 3 & 7 \\
\hline United Kingdom & 68000 & 61000 & 36000 & 30000 & 46000 & 36000 \\
\hline
\end{tabular}

Source: own elaboration based on the OECD data

Chinese and Indian migrant communities are sometimes the subject of comparison in minority and migration studies (Li 2007; Chand and Ghorbani 2011). Chand and Ghorbani (2011) compared Chinese and Indian immigrant communities with respect to cultural values and social capital. The authors claim that some of the dimensions, such as future orientation of individuals, humane orientation, uncertainty avoidance, and gender egalitarianism show inconsistent scores on comparative assessments of Chinese and Indian cultures, while on the other hand they do not perceive them as completely relevant to the studies of the ethnic 
entrepreneurship. They suggest that assertiveness, performance orientation and collectivism (in-group and societal collectivism), are the key dimension to evaluate when the potential for opening and running ethnically-based enterprises. However, discussing the similarities between the two communities, other dimensions apart from ethnic origins should be taken into account. Chinese and Indian migrants, despite originating from culturally and politically different regions, share a set of important common determinants of their position in Poland.

First of all, as third country nationals from Asia, Chinese and Indian migrants are subject to the same set of legal provisions regulating inflow of foreigners and their integration in Poland. They are not encompassed by the regime of simplified employment procedure (as in case of citizens of Ukraine, Georgia, Russia, Belorussia, Moldova, Armenia) nor by the privileged principles of permanent stay and integration envisaged for migrants from post-Soviet states who have Polish origins (Card of the Pole, act on repatriation). This differentiation of statuses of third country nationals from Soviet and non-Soviet area means that the Chinese and Indian migrants are in the "underprivileged" group of third country nationals.

Since the Polish labour market demand for foreign labour focuses mostly in seasonal works and sectors offering temporary jobs, migrants from neighbouring states are preferred. This is reflected by the construction of the system of simplified employment procedure, which is addressed mostly to foreigners from geographically close states ${ }^{3}$. Standard, long-term employment in Poland favours the members of the native population (the system of complementary employment of foreigners) and therefore third country nationals from non-Soviet area may find it difficult to succeed in the process of economic integration. As a consequence of problems with the labour market activation, generally immigrants often choose self-employment as a strategy of counteracting difficulties and threat of economic marginalisation (see for example: Waldinger, Aldrich, Ward et al. 1990; Kloosterman, van der Leun, Rath 1999; Volery 2007). This trend can be also observed in case of Chinese and Indian migrants in Poland where self-employment is frequent.

Second, the inflow of Chinese and Indian migrants intensified as a result of Poland joining the European Union in 2004 (as the narratives suggest, the attractiveness of Poland as a host country grew in the time of the accession negotiations). In the 1990s, the immigrant communities from these countries were scarce. Poland is an attractive receiving state because of its membership in the European Union. Immigrants from India and China do not choose Poland because of cultural proximity, but they rather make rational decisions basing of Poland's status as an EU

${ }^{3}$ Since the beginning of 2018, the system of simplified employment will be complemented by the provisions imposed by the Seasonal Workers Directive (2014/36/EU), addressed to third country nationals from all states. However, the long period of functioning of the simplified system consolidated the model of temporary work of foreigners form the neighbouring states. 
member state. In addition to that, the entrance of Poland into the Schengen zone in 2007 was also an incentive to come for some third country nationals.

Third, the networking of immigrant entrepreneurs is based on various forms on business associations. In case on Chinese entrepreneurs, as well as in case of Indian entrepreneurs, a variety of organisations supporting business exist in Poland. Some of them unite only immigrant entrepreneurs, others are aimed at the cooperation with Polish partners. In case of the Chinese community, these organisations include Association of Chinese Entrepreneurs in Poland, registered in 2011 and Polish-Chinese Business Council registered in 2013. In case of Indian community, their business activities are supported by the Indo Polish Chambers of Commerce and Industries (PICCI) set up in 2007 and Polish-Indian Economic Chamber established in 2008. Chinese and Indian migrants come from countries which are culturally heterogeneous: in terms of languages, religions, and ethnic groups. Although in both communities there exist associations based on common aspects of cultural heritage (e.g. religious organisations), the development of specialised organisations focusing at business activities facilitates the expansion of immigrant entrepreneurship.

In the Polish migration literature we can observe a growing interest in the presence, structure and dynamics of communities from China and India. It is indicated that the number of immigrants from China is growing, and significant categories within this community are entrepreneurs and workers of Chinese firms (Wardęga 2017). Although Chinese migrants started coming to Poland after 2004, Chinese minorities were already present in other Central European countries; individuals who came after Polish accession to the EU usually did not come straight from China and had experience of migration in countries like Czech Republic and Hungary (Wysieńska, Piłat 2012). Chinese immigrants often turn for help and assistance to Vietnamese immigrants, who have a longer history in Poland as an ethnic community and are much better integrated with the host society (Wysieńska 2012). However, as K. Wysieńska emphasises, the relations between migrants (especially entrepreneurs) from the two diasporas are complicated and problematic which is reflected for example by conflicts between traders in Wólka Kosowska. As J. Wardęga indicates, the growing presence of Chinese business in Poland is a consequence of the New Silk Road project. The project which is also known as One Belt One Road Initiative, is a strategy of economic development, implemented since 2013, which focuses on intensifying the connections between Asian and European countries. The migration researchers so far concentrated on the micro-entrepreneurs who conduct business activities (even unregistered) in multicultural bazaars and trade centers, such as Wólka Kosowska or Marywilska Street in Warsaw.

The Indian community has a very entrepreneurial profile, too. I. Bąbiak distinguished several categories of Indian immigrants who display diverse strategies 
of economic activities. The first group are investors who come because they have their financial assets located in Poland. The second group are entrepreneurs who set up their firms in Poland. The third group are migrants who perform various jobs (sometimes temporary and odd) in Indian companies. The fourth groups are workers of international corporations. The fifth group are workers employed in Polish firms (Bąbiak 2015: 49). It is easy to observe that most of these categories are somehow connected with business activities in the host country. Indian migrants who develop their enterprises in Poland were found to rarely use the immigrant networks in their business activities, contrary to what is observed in Western Europe (Nestorowicz 2013). As Joanna Nestorowicz explains, the reason may be relatively small Indian community in Poland and the fact that entrepreneurs with developed firms were actually pioneers of migration. Moreover, lack of support from the co-ethnics may be caused by competitiveness and strong market orientation within the community; in other areas of social life (non-business related activities) the Indians were more prone to use ethnic networks (Nestorowicz 2013). As indicated by the Embassy of India in Poland \& Lithuania, Indian investments in Poland are worth over 3 billion US dollars. The Indian companies operating in Poland include ArcelorMittal, Strides Arcolab, Reliance Industries, Ranbaxy, Essel Propack.

\section{Indian and Chinese business activities: the official statistics}

The data about business entities with foreign capital demonstrate that both Chinese and Indian investors are present in Poland. Taking into account the amount of foreign shareholder's capital, China is the fourth biggest investor among the non-EU/EEA states, while India is the thirteenth biggest investor in this category. However, taking into account the criterion of number of shareholders from each state, investors from China are the second largest group (after Ukrainians) while investors from India are in the eighth place. As of 2015, there were 839 entities with Chinese capital and 121 entities with Indian capital in Poland. These numbers encompass both the shareholders who invest from abroad as well as those who reside in Poland.

Despite the data from GUS provide an important context for the analysis of Chinese and Indian entrepreneurship in Poland, these data do not enable to determine how many shareholders reside in Poland and how many of them operate from abroad. The number of migrant entrepreneurs living in Poland can be estimated on the basis of two other statistical compilations. First, the data from the Ministry of Family, Work and Social Policy provide information of migrants working in management boards of companies. It encompasses migrants who need a work permit to perform such duties in Poland. The second type of data is statistics of 
Table 3 .

Foreign capital in Poland - non-EU/ non-EEA countries

\begin{tabular}{|l|c|c|c|c|}
\cline { 2 - 5 } \multicolumn{1}{c|}{} & $\begin{array}{c}\text { Number } \\
\text { of entitites }\end{array}$ & $\begin{array}{c}\text { Number } \\
\text { of shareholders }\end{array}$ & $\begin{array}{c}\text { Foreign } \\
\text { shareholders' } \\
\text { capital } \\
\text { (in mln pln) }\end{array}$ & $\begin{array}{c}\text { Country share } \\
\text { in the whole } \\
\text { foreign capital } \\
\%\end{array}$ \\
\hline USA & 785 & 967 & 7515,7 & 3,69 \\
\hline South Korea & 137 & 194 & 2299,1 & 1,13 \\
\hline Japan & 73 & 81 & 1366,1 & 0,67 \\
\hline China & $\mathbf{8 3 9}$ & $\mathbf{1 5 7 5}$ & $\mathbf{5 4 6 , 1}$ & $\mathbf{0 , 2 7}$ \\
\hline Canada & 116 & 136 & 320,6 & 0,16 \\
\hline Hongkong & 38 & 40 & 298,0 & 0,15 \\
\hline Israel & 170 & 236 & 263,3 & 0,13 \\
\hline Turkey & 186 & 306 & 130,9 & 0,06 \\
\hline Ukraine & 1132 & 2212 & 118,6 & 0,06 \\
\hline Russia & 305 & 461 & 117,8 & 0,06 \\
\hline Singapur & 24 & 25 & 98,1 & 0,05 \\
\hline Virgin Islands GB & 54 & 55 & 95,6 & 0,05 \\
\hline India & $\mathbf{1 2 1}$ & $\mathbf{1 7 3}$ & $\mathbf{3 8 , 0}$ & $\mathbf{0 , 0 2}$ \\
\hline
\end{tabular}

Source: Central Statistical Office, GUS 2016 (data as of 2015)

the Zakład Ubezpieczeń Społecznych (ZUS) about self-employed who pay social security contributions in Poland.

The statistics on the work permits type B show the number of immigrants who apply for an authorisation of work in a management board of a company. In years 2011-2015, Chinese immigrants obtained more work permits of this type than Indian immigrants. However, in 2016 the number of registrations in both groups was the same. A huge dynamics can be observed in the amount of registrations. Within the timespan under consideration, the highest number of work permits was registered in 2011-2012. Since that time, we observe a decrease in the number of registrations in both communities (Chinese and Indian) as well as among foreigners as a whole. It has to be emphasised that migrants with stable residency statuses (permanent stay, long-term EU residency) may work in the host country without any limitations and do not have to apply for such permit. When they register companies and work in management boards they are invisible for the statistics. The growing number of immigrant with secure legal statuses may be thus partly 
Table 4 .

Work permits type B (for migrants who want to work in companies' management)

\begin{tabular}{|c|c|c|c|}
\hline $\begin{array}{c}\text { Work permits type B } \\
\text { (work in company } \\
\text { management) }\end{array}$ & India & $\begin{array}{c}\text { China } \\
\text { (not counting } \\
\text { Taiwan) }\end{array}$ & Total foreigners \\
\hline Issued in 2016 & 12 & 12 & 312 \\
\hline Issued in 2015 & 7 & 9 & 315 \\
\hline Issued in 2014 & 14 & 47 & 541 \\
\hline Issued in 2013 & 32 & 120 & 860 \\
\hline Issued in 2012 & 34 & 139 & 1052 \\
\hline Issued in 2011 & 43 & 187 & 1048 \\
\hline
\end{tabular}

Source: own elaboration based on statistics of the Ministry of Family, Work and Social Policy, https://www.mpips.gov.pl

responsible for the smaller number of migrants applying for permits to work in companies' management. In both communities, the most popular sector chosen by migrants who work in management boards is wholesale trade and retail trade.

The second type of entrepreneurial activities is individual business activity (działalność gospodarcza osoby fizycznej). It is much better suited for the needs of micro-entrepreneurs who are the majority of immigrant entrepreneurs. It is cost-effective and the accountancy aspect is simple. It is also flexible (can be suspended for a maximum of two years). This business form gives more opportunities to succeed as entrepreneurs because of reduced costs and flexibility. However, at the same time it is much less accessible for foreigners. The possibility to register such business venture is almost exclusively limited to individuals who have stable residency statuses. The most important statuses which enable registering own venture include: permanent residency card, long-term EU residency card, stay of a spouse of a Polish citizen, various forms of forced migration including refugee status (for a detailed analysis, see: Andrejuk 2016). This is connected with a very important aspect of economisation of ethnicity: immigrants who want to set up a more advantageous form of business venture, need a secure legal status in Poland. As of September 2018, 146 Chinese self-employed and 225 Indian self-employed individuals in Poland were registered at the Polish Social Insurance Office (ZUS 2018). The Chinese entrepreneurship in Poland is also enhanced by the $16+1$ initiative, which promotes Chinese cooperation and investment in Central and Eastern European countries (Ping, Zukoi eds.: 2018). 


\section{Reducing negative impact of ethnicity: integration with the host society}

Several respondents in the sample have been residing in Poland for dozen or more years. The success of their enterprises in not only a result of firms' long-term development, but also the solid amount of experiences of migrant entrepreneurs with the host society and host labour market. Some Chinese and Indian entrepreneurs from the sample started their businesses in Poland at the beginning of 1990s when Poland experienced the transformation of the economic and politic system and transited from planned to market economy. It was a moment when foreign goods were introduced to the Polish market and especially import-export businesses were flourishing. Additionally, some Indian businessmen mentioned that Poland due to its geographical location between East and West was a perfect spot to operate sales to Russia and other former USSR states. Next milestone in the Polish history was joining the EU, which also had impact of immigrants' businesses in Poland. It is interesting that even before the formal accession to the EU (respondent mentions 1999-2002), Poland was attractive for immigrants just because of the anticipated status of an EU member state:

I think it started in 2001. In 1989, 1992 the companies were entering the Polish market, there were a lot of investments, but the real boom was in 1999-2002 when it became clear Poland will join the EU"' [Indian, male, owner of the travel agency]

In this part, we discuss several mechanisms of counteracting various barriers in the labour market. The first is strengthening one's legal position and thus removing formal, structural obstacles to both employability and self-employment. The second is taking advantage of the social capital of the host country by bi-national marriages. The third is reducing the cultural distance and improving the quality of cultural capital especially by gaining linguistic competences. In the context of developing business activities, probably the most important dimension of integration is the acquisition of a secure legal status: permanent residency or Polish citizenship. The narratives demonstrate that certain aspects of business activities (frequent international travels) and the aim of smooth conduct of occupational duties were a factor facilitating the decision to naturalise:

- When was it [naturalisation]?

- I think it was in 2004.

- So you had been in Poland for quite a long time then?

- Yes. I could have done it earlier, but there was no need. [At that time] I went abroad a lot, every time I needed a visa and so my professional travels had lot of delays. And we decided that we would live here, so it was easier for me and I got the citizenship. [male, Indian, restaurant] 
For other migrants the permanent residence permit is enough, because it formally enables professional activities to the same extent as in case of native population. Migrant entrepreneurs demonstrate familiarity with the Polish legal context, and they appreciate the positive role of a secure residency status, which entitles to perform economic activities without separate administrative procedure of obtaining work permit. Nevertheless, the narrative below suggests that the system of permits for immigrant work and lengthy bureaucratic procedures connected with this regime may still influence the development of firms of business owners with a permanent status. Permanent residents may experience difficulties when they attempt hire co-ethnics as employees:

- I have permanent residency now.

- Oh, so you have permanent residency.

- Since I have it, I don't need a work permit. Now I need a work permit for my employee.

- So that's how it is...

- I have to do it every year, now every two years. It is a big problem.

- Is it? Is it difficult to do?

- Oh my God! You know what, if you have time, you should once go to Dtuga 5 [past location department of foreigners' affairs, Warsaw]

- Yes, I go there sometimes...

- Go to this office and look. There is no worse office in Poland. [male, Chinese, alternative medicine]

Some immigrants prefer to remain citizens of the sending state, but they obtain a secure legal status in Poland because of pragmatic reasons:

I have Chinese citizenship. It has not come to my mind to apply for Polish citizenship, because I have permanent residency card, which makes my life easier. But I have a Chinese passport, so I don't have problems with going back to the country. I think that I remained Chinese citizen mostly because it is convenient. [female, Chinese, trade]

Another strategy of reducing risk associated with foreign origins is setting up a family firm with a spouse of Polish nationality. This strategy seems to be much more common among Indian migrants than Chinese however. Especially in the first period of stay in Poland, it may work as a strategy of circumventing limitations, which result from unstable legal status. Developing a business venture with a Polish spouse creates a safer situation, which is a result of better understanding of a cultural context of the host society, awareness of Polish customers' needs and preferences, knowledge of a complicated and frequently modified legal framework. These aspects may not be fully realised by immigrants starting their business activities, but they do improve the situation of a new venture. As the narrative below demonstrates, the enterprise developed with a Polish spouse may be the first stage of the business development. The respondent gained more independence in the 
later period, while his Polish partner limited their participation in his business ventures because of childcare duties:

- The first firm was with my wife, the child was born in 1997, and at that time my wife was a bit at home, then we started working together in our first business in 1997, I opened my first firm when [son] was born, in 1999 the second one. How long - I don't remember, in ten years I will remember nothing.

- Was the first firm with your wife?

- Textile, we bought textiles here and we sold them further to other customers, so trade company, we bought from importers and sold [materials] further. The firm was very well, but my wife told me, the child was at home all the time. And we decided that I will lead the household, I will work, and my wife will stay with the child [male, Indian, restaurant]

Language learning is an important aspect of developing an immigrant business in Poland. The Indians speak English, which is an official language in their country of origin. Knowledge of English is common among high-skilled individuals in Poland, however, the migrant business ventures usually employ low-skilled professionals. Low-skilled native workers do not speak English which may constitute an obstacle in smooth conduct of business activities. Indian entrepreneurs perceive learning Polish as a strategy enabling a better communication within the firm:

- How did you learn Polish?

- When we opened the shop, the workers there were Polish. They did not understand English, and I did not understand Polish. But I had to talk. And slowly, slowly they taught me speak better. And I understood a bit, I talked a bit. I had a teacher for a month, but it was not good... one must talk. We had a retail shop. We had a secretary, she translated. When one must understand, then it is easier. [female, Indian, trade]

Sometimes the ethnicity in business conduct is invisible, because, as respondents declare, it does not bring any added value to their economic activity. "Ethnic" component is practically losing relevance in sectors which are concentrated on working with the Polish clients or demand specific educational background. In case of travel agency, language school or IT, but also in case of waiters in the oriental restaurants, profession competences and goal-orientation are declared to be the essential characteristics of the employee. The Indian owner of the travel agency summarized it the following way:

I do not see the problem [employing the Indians], but the sector has its specificity. It is about the sector. I guess in sales, such as importing or exporting goods, it is easier. Here we need a person who has qualifications, has a solid knowledge of geography. We prefer someone who has a degree in tourism management. I think it is one of the reasons why we employ so few foreigners, including Indians [male, Indian, travel agency] 
To sum up: contrary to many studies on migrant entrepreneurship, ethnic resources are emphasized and cherished by entrepreneurs only in case of traditional enterprises oriented on ethnic customer, however for global or locally-oriented business endeavours other aspects become valuable assets for potential employees and the entrepreneur him/herself. Many ethnic entrepreneurs would rather turn to the resources of the host country in order to improve their situation in the labour market than stick to their ethnic networks.

\section{Using ethnic cultural and ethnic social capital in business}

While the academic literature quoted above recognizes the role of ethnic resources in migrants' entrepreneurial activities, research usually overlooks the selectivity of the ethnic capital used in the self-employment. We argue that migrants choose to utilise particular assets, which they perceive as advantageous in the process of business development. This does not exclude the parallel mechanism of limiting the potential impact of ethnicity in other contexts for example in the legal sphere (through naturalisation).

One of the most important mechanisms is making use of the networks within the ethnic community to minimise the costs and maximise the utility of business ventures. Respondents indicated at employment of co-ethnics in their firms. The first reason was the qualifications of such workers - their skills acquired in the sending country, such as specific Chinese massage or cooking specific meals. Another reason was foreign workers' relatively less privileged position in the Polish labour market and their relative ignorance about the Polish labour law, which force them to consent to work without a regular employment contract with its entitlements. For example, the owner of the language school (Indian female entrepreneur) mentioned that employing Polish teachers demanded more paperwork, since they are interested in permanent employment which ensures the retirement contributions, while foreigners (including Indians) are willing to accept the casual employment and receive higher salary while paying minimal social security contributions in Poland.

Cultural assets (especially those recognised by the host society, and deemed "exotic") may also be used in an effort to achieve higher position in the labour market and prestige, to improve performance and generally instigate firm development. Immigrants set up their enterprises in sectors, which allow them to capitalise cultural competences. The attractiveness of ethnic products for local customers translates into development of migrant firms in various branches, such as ethnic cuisine or alternative medicine (acupuncture, acupressure, Chinese massage).

This is a massage cabinet, Chinese massage... Kind of acupressure, Chinese massage and I may say healing massage... luxury one. And more healing. They are not very relaxing. 
It is a bit... maybe you heard that... it hurts a bit. And now many Poles like it, they take good care of themselves, of their health. For example, body massage or foot massage. [- Uhm] - You were in China, so you know, foot massage is very popular in China, and it is good for one's health. Now many Poles go to China and many people know that. They prefer... Some people prefer to pay money and not be afraid of getting sick [in the future]. Because they could have got sick later, spend money on a doctor, on medicines. Some people think differently now. And we open such cabinets and many people come, they are just satisfied. [Chinese, male, alternative medicine]

Poles do not understand that (the specificity of the Indian cuisine). You must understand how to use our spices, each meal is associated with the specific spices, each type of meat is associated with specific spices, each meal is cooked in the specific way. I do not see how Poles can do that [male, Indian, restaurant]

Another aspect of taking advantage of ethnic resources in business is capitalising ethnic bonds and intra-group loyalty. The studies of Chinese immigrant entrepreneurs frequently emphasise the significance of ethnic networks based on solidarity and cooperation (guanxi) which enable successful conduction of business activities (Li, Moreira 2009; Obłój, Zhang 2011; Willemse 2014; Chester 2016). The phenomenon, originating from an old Confucian concept, is also studied in reference to Chinese entrepreneurs in their native country (Lee, Anderson 2007). The phenomenon of Chinese ethnic networks is visible in Wólka Kosowska, where many firms (trading points) are ran by family members, relatives or individuals from the same region of China. Chinese respondents define the specificity of their cultural background by referring to solidarity in their community:

When I can't have something, and I need it, well. My family, my friends don't laugh at me. Right? They... And Poles are more simple. When one doesn't have it, then one does not. When one cannot afford something, then one cannot [have it]. They are ashamed, they laugh. And Chinese - if you don't have something, if you cannot afford it, you can lend money, and give it back afterwards. Otherwise it would be shameful. This is the difference between the Chinese and Poles. [Chinese, male, alternative medicine]

Of course, profits, earning more is important. But everyone must be open and fair, keep the promises. For Chinese people, it is the most important thing. If I buy goods from you, ever if these goods cost few thousand zlotys, you know that I will pay for it on time. I think this intergroup trust and fairness is beneficial for Chinese people". [Chinese, female, import)

However, the dark side of ethnic networks was also stressed by some narratives. For instance, Chinese female businesswoman mentioned being excluded from the Chinese community after divorce. In Chinese culture divorced woman is an outcast. 
Capitalising ethnic networks is apparent not only in the Chinese community. This mechanism is visible in many migrant groups (eg. Zhou 2004, Waldinger, Aldrich, Ward 1990) and was also observed among the Indian self-employed in Poland. The narrative of a woman who develops her firm together with an Indian husband, proves the family character of an Indian business venture. As it is demonstrated in the narrative, mobility (temporary or permanent) encompassed various members of an extended family. Some of them work in the enterprise, while others assist with different type of duties (childcare):

One of my brothers [is] also in the business, there was an office and he did the trade, he [has been here] for six years, his family, wife, a daughter was born here. He has been there seven years. I have two brothers, they were all here, they came. My mother came when I had a baby, she spent three months here. And my dad as well. Now dad is gone, but seven years ago he came twice. My family, my husband's family [came]. [female, Indian, trade]

But also non-blood ties may be important driver for the business activities abroad. As an example, we can consider the following quote by Indian restaurant owner:

Us, Indians, we help each other. I never felt lonely if I had two Indians around me, who, let's say, came here (to Poland) earlier. They supported me a lot [male, Indian, restaurant]

Family firms established by respondents are diverse: some of them are developed together with a Polish spouse, others have solely ethnic character. While the development of either of these typed depends on the personal situation of respondents, two categories of family firms differently profit from social capital embedded within their structure. While immigrant firms co-led by a Polish spouse may find it easier to operate in the Polish institutional context, the immigrant firms developed by various ethnic family members have more extensive transnational networks and may use the ethnic capital in diverse forms.

I think Indians are very closed community in Poland. My wife is Polish, so I opened up to Poland, learned the language and I feel at home in Poland. I feel even more at home here than I did in India. [...] I never lived in the Indian neighbourhood [male, Indian, restaurant]

One additional aspect which is not that obviously ethnic component, but can be effectively utilized in running business abroad is specific leadership style both Indian and Chinese entrepreneurs tend to exercise. Chinese female entrepreneur confirms these findings saying that:

In China all leaders treat their people just as they would treat their children. They love them and take care of them, but sometimes due to being older, they also can be critical. I think it is a typical Chinese feature. [female, Chinese] 
In case of Indian leadership strategies, the results are less coherent, since on one hand some Indian businessmen stress that they rely on their teams and do not feel like autocratic leaders: "I cannot say this company is mine, I cannot say I am the one who does everything. This company is the fruit of many people's work" (Indian businessman, travel agency). Other Indian entrepreneur, the owner of the restaurant's chain, also stressed that his management strategy is human oriented, however he can be demanding boss: "The traditional approach in India is appreciating of the good employee. If a person works for you for 20 years, you can even pay for his kid's education if he cannot afford it. People in India expect such attitude. I am such a good boss here in Poland, and I am proud that they (employees) love me and do not lie to me". The same interviewee mentioned that some people work in his restaurants for 12 to 18 years and every employee is appreciated and treated with the greatest respect. One of the explanations for the mixed results in Indian community can be found in fact that almost all interviewees are married to Polish women and live in Poland for a long time, hence their business strategies are probably more flexible than in India. Additionally, there might be a social desirability effect in these narratives on the good leadership.

\section{Summary}

The article presented the concept of economisation of ethnicity, demonstrating how immigrants from China and India actively manage their ethnicity in the process of labour market integration. The aim of reducing potentially marginalising or discriminatory impact of ethnicity may be accomplished through: acquisition of Polish citizenship or a stable legal status in Poland; familiarising with Polish legal regulations concerning the employment of foreigners and other aspects of business activities; learning host country's language; setting up family firms with Polish spouses; reducing the visibility of ethnic component in branches where ethnicity does not provide a competitive advantage. The process of capitalising ethnic resources can be performed through: reference to cultural patterns of co-ethnic friendship, solidarity and intra-group loyalty; employment of co-ethnics; capitalising cultural competences in certain sectors of business; establishing transnational links to cooperate with ethnic business partners. This list is not exhaustive. An indispensable aspect of the business conduct is selectivity of ethnic assets, which migrants utilise in the entrepreneurial process. The phenomenon of economisation of ethnicity in its both dimensions may also take other forms in other migrant communities. While the two components of the economisation process tend to be understood as opposite, we show that they are co-existent and complement each other. Such approach allows one to capture more comprehensively the dynamic, intricate routes of inclusion and alienation of ethnic groups. 


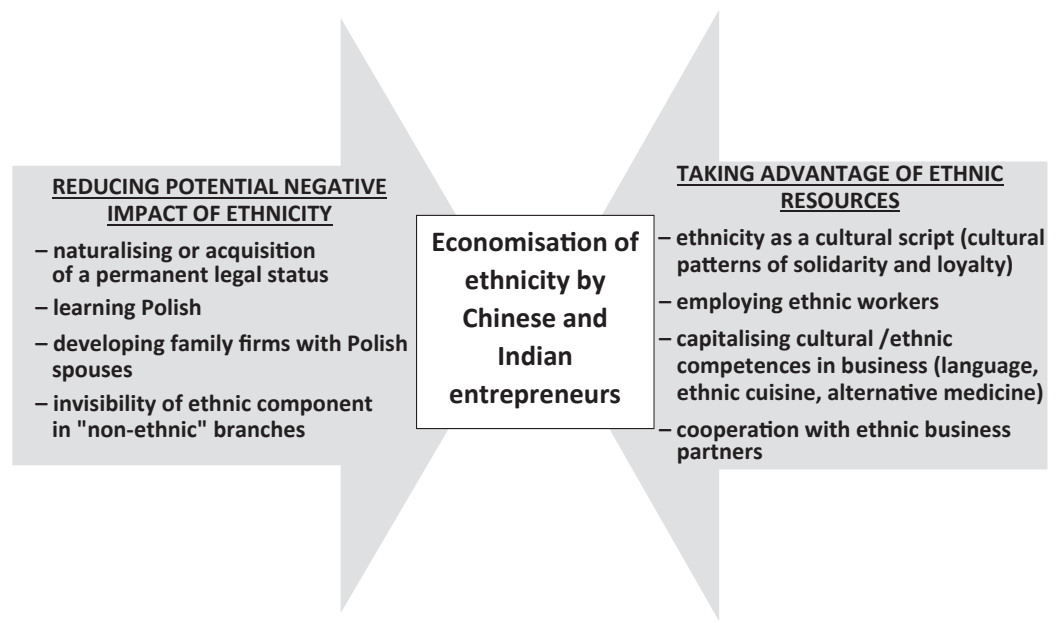

Source: own elaboration

The two groups of third country nationals: Indian and Chinese migrants, in spite of some similarities, also show differences in the patterns of social activities in the host country. The Indian migrants seem to be more open towards binational marriages and employers from outside their group, while the foreigners from China appear to have more homogeneous networks and to nurse deeper intra-community ties. Another difference is migrants' language proficiency in English: for Indians it is one of the official languages of their country of origin. The knowledge of an international language may give them a competitive advantage in the business sphere, leading i.a. to better opportunities of international firm development.

While the study focused on the case of migrant entrepreneurs, the concept of economisation of ethnicity may be also used to examine the patterns and mechanisms of economic integration of contractual workers or individuals performing other forms of subordinate employment. It is not limited to studying Chinese and Indian immigrants and may provide a meaningful theoretical tool for examination of economic activities of other immigrant groups. Our research also demonstrates that two strands of academic literature: the research about migrant integration/ assimilation and the research about ethnic entrepreneurship, which were developed independently and separately, may be cross-fertilising and complement each other's findings.

\section{References}

Andrejuk K. (2016), Prawne uwarunkowania tworzenia i rozwijania przedsiębiorstw przez cudzoziemców w Polsce, „Polityka Społeczna” nr 3/2016, pp. 18-24.

Bąbiak I. (2015), Poland czy Holland... Praca Hindusów w Polsce, [w:] I. Bąbiak, K. Gmaj (red.), Namaste Polsko! Sytuacja i potrzeby imigrantów z Indii w Polsce, Scholar, Warszawa, pp. 47-59. 
Bevelander P., Veenman J. (2006), Naturalisation and Socioeconomic Integration: The Case of the Netherlands, IZA Discussion Paper No. 2153

Chester H. C., (2016), Global Channels Of Successful Immigrant Entrepreneurs Illustrate The Constructal Law, "International Journal Of Heat And Technology", Volume 34, Special Issue 1, pp.S29-S36 http://dx.doi.org/10.18280/ijht.34S104

Çalışkan K., Callon M., (2009), Economization, part 1: shifting attention from the economy towards processes of economization, "Economy and society", vol 9, pp. 369-398

Comaroff J. L., Comaroff J. (2009), Ethnicity Inc., University of Chicago Press.

Dustmann C., Glitz A., Vogel T. (2010), Employment, wages, and the economic cycle: Differences between immigrants and natives, "European Economic Review", vol. 54/1, pp. 1-17.

GUS (2016), Economic activity of entities with foreign capital in 2015 (retrieved from: https:// stat.gov.pl)

Huang Ping, Liu Zukoi (eds.) (2018), „16+1” Cooperation and Chinese Investments in CEEC, China-CEEC Think Tank Book Series.

Jóźwiak I. (2012), „Nowa” imigracja z Chin i Wietnamu a społeczności lokalne - Jaworzno i Wólka Kosowska, [in:] Wysieńska K. (ed.), Sprzedawać, gotować, budować? Plany i strategie Chińczyków i Wietnamczyków w Polsce, Warsaw: Institute of Public Affairs.

Kloosterman, R., van der Leun J., Rath J. (1999), Mixed embeddedness. (In)formal economic activities and immigrant business in the Netherlands, "International Journal of Urban and Regional Research", volume 23(2), pp. 253-267.

Kogan I. (2004), Last Hired, First Fired? The Unemployment Dynamics of Male Immigrants in Germany, "European Sociological Review”, vol. 20 number 5, pp. 445-461

Lee E. Y., Anderson A. R. (2007), The Role Of Guanxi In Chinese Entrepreneurship, "Journal of Asia Entrepreneurship and Sustainability", Volume III, Issue 3, December 2007.

Li T., Owen M. G. (2009), The Influence of Confucianism and Buddhism on Chinese Business: the Case of Aveiro, Portugal, Journal of Intercultural Communication, issue 19, January 2009.

Masud C., Ghorbani M. (2011), National culture, networks and ethnic entrepreneurship: A comparison of the Indian and Chinese immigrants in the US, "International Business Review" 20, pp. 593-606.

Nestorowicz J. (2013), Do the networks do the works, Central and Eastern European Migration Review, Vol. 2, No. 2, pp. 5-19.

Volery T. (2007), Ethnic entrepreneurship: A theoretical framework, in: P. Leo Dana (ed.), Handbook of Research on Ethnic Minority Entrepreneurship, Cheltenham: Edward Elgar, pp. 30-41.

Waldinger R. D., Aldrich H., Ward R. and Associates (1990), Ethnic entrepreneurs: immigrant business in industrial societies, London: Sage Publications.

Wardęga J. (2017), Chińczycy w Polsce - niewidoczna mniejszość, "Studia Migracyjne-Przegląd Polonijny", 2/2017, pp, 121-141.

Wei L. (2007), Ethnic Entrepreneurship: Studying Chinese and Indian Students in the United States, "Journal of Developmental Entrepreneurship", Vol. 12, No. 4, pp. 449-466.

Willemse L. (2014), The Role of Economic Factors and Guanxi Networks in the Success of Chinese Shops in Johannesburg, South Africa, "Urban Forum", March, Volume 25, Issue 1, pp. 105-123. https://link.springer.com/article/10.1007/s12132-013-9202-4

Wilson, K., Portes A. (1980), Immigrant Enclaves: An Analysis of the Labor Market Experience of Cubans in Miami, "American Journal of Sociology", vol. 86, pp. 295-319. 
Wysieńska K., Piłat A. (2012), Ekonomiczna adaptacja chińskich i wietnamskich imigrantów zarobkowych, [in:] Wysieńska K. (ed.), Sprzedawać, gotować, budować? Plany i strategie Chińczyków i Wietnamczyków w Polsce, Warsaw: Institute of Public Affairs.

Zhou M. (2004), Revisiting Ethnic Entrepreneurship: Convergencies, Controversies, and Conceptual Advancements, "International Migration Review" Volume 38, Issue 3, September, pp. 1040-1074.

ZUS (2018), Liczba ubezpieczonych, którzy w zgłoszeniu do ubezpieczeń emerytalnego i rentowych $^{\star}$ ) podali obywatelstwo inne niż polskie (retrieved from: psz.zus.pl) 